NBER WORKING PAPER SERIES

\title{
EDUCATION AND INNOVATION: \\ THE LONG SHADOW OF THE CULTURAL REVOLUTION
}

\author{
Zhangkai Huang \\ Gordon M. Phillips \\ Jialun Yang \\ Yi Zhang \\ Working Paper 27107 \\ http://www.nber.org/papers/w27107 \\ NATIONAL BUREAU OF ECONOMIC RESEARCH \\ 1050 Massachusetts Avenue \\ Cambridge, MA 02138 \\ May 2020
}

We appreciate the helpful suggestions from seminar participants at Southern University of Science and Technology, Development Economics Workshop at Peking University, The Ronald Coase Institute Workshop on Institutional Analysis in University of Warsaw (2019), 12th International Accounting \& Finance Doctoral Symposium in Milan (2019), Asian Meeting of the Econometric Society (2019), China Financial Research Conference (2019), Ph.D. Poster Session at the AFA Annual Meeting (2020). The authors are responsible for all the remaining errors. The views expressed herein are those of the authors and do not necessarily reflect the views of the National Bureau of Economic Research.

NBER working papers are circulated for discussion and comment purposes. They have not been peer-reviewed or been subject to the review by the NBER Board of Directors that accompanies official NBER publications.

(C) 2020 by Zhangkai Huang, Gordon M. Phillips, Jialun Yang, and Yi Zhang. All rights reserved. Short sections of text, not to exceed two paragraphs, may be quoted without explicit permission provided that full credit, including $(\odot$ notice, is given to the source. 
Education and Innovation: The Long Shadow of the Cultural Revolution

Zhangkai Huang, Gordon M. Phillips, Jialun Yang, and Yi Zhang

NBER Working Paper No. 27107

May 2020

JEL No. G3,I23,J24,O31,O32

\begin{abstract}
$\underline{\text { ABSTRACT }}$
The Cultural Revolution deprived Chinese students of the opportunity to receive higher education for 10 years when colleges and universities were closed from 1966-1976. We examine the human capital cost of this loss of education on subsequent innovation by firms, and ask if it impacted firms more than 30 years later. We examine the innovation of firms with CEOs who turned 18 during the Cultural Revolution, which sharply reduced their chances of attending college. Using multiple approaches to control for selection and endogeneity, including an instrument based on whether the CEO turned 18 during the Cultural Revolution and a regression discontinuity approach, we show that Chinese firms led by CEOs without a college degree spend less on R\&D, generate fewer patents, and receive fewer citations to these patents.
\end{abstract}

\author{
Zhangkai Huang \\ School of Economics and Management \\ huangzhk@sem.tsinghua.edu.cn \\ Gordon M. Phillips \\ Tuck School of Business \\ Dartmouth College \\ 100 Tuck Hall \\ Hanover, NH 03755 \\ and NBER \\ gordon.m.phillips@gmail.com
}

\author{
Jialun Yang \\ Tsinghua University \\ Beijing \\ China \\ yangj1.16@sem.tsinghua.edu.cn \\ Yi Zhang \\ Nottingham University \\ Beijing \\ China \\ cherry-yi.zhang@nottingham.edu.cn
}




\section{Introduction}

A key insight from Romer (1990) is that human capital is critically important to economic growth through research and the production of ideas. As Romer discusses, each person accumulates human capital through both education and training. The generation of new ideas through human capital can also lead to positive knowledge spillovers that raise the productivity of other researchers, giving rise to endogenous economic growth. This growth can be sustained through the accumulation of inputs that generate these positive externalities, such as access to education and on job training.

Many firms seek to capitalize on the human capital of their employees by organizing in such a way that maximizes positive spillover effects. Firms can encourage innovation and human capital sharing in multiple ways, e.g., through hiring practices, incentive systems, and a company culture that tolerates failure in the pursuit of new ideas. Often, a firm's CEO is responsible for setting a culture that can either encourage or discourage innovation. We examine the importance of education to new ideas and innovation by examining the impact of education on innovation by firms through the leadership their CEOs. In this paper, we examine if the CEO’s education influences innovation that arises from the firm.

We use a particular historical episode of China-- the Cultural Revolution (1966-1976) to examine the lingering impact of closing universities and colleges on firms over 30 years after the Cultural Revolution. The Cultural Revolution was one of the largest adverse events in the 20th century. It not only affected millions of Chinese-political elites and ordinary people alike—but also prevented individuals from accessing higher education during peak college learning years due to the government shut down of all colleges and universities. Chinese students were unable to obtain higher education for a ten-year period, until the colleges and universities were reopened in 1977. During this time, an entire cohort of students missed their opportunity to attain formal higher education during their peak learning years. We explore how access to education in key college attendance years can impact firm spending on R\&D and innovation and use the Cultural Revolution as a negative shock that impacted individuals for a generation. ${ }^{1}$

\footnotetext{
1 See Li and Meng (2017) document evidence on the scarring impact of the Cultural Revolution. Affected individuals experienced sizeable reductions in earnings and wealth that persisted for over 30 years.
} 
When the Cultural Revolution finally ended in 1976, individuals who missed the chance to attend college could take the college admission test in the winter of 1977 and enter college in the summer of 1978. However, even if they decided to retake the test and give up the job they may currently held, they would have had to compete with new high school graduates who were perhaps better prepared for the entry test. Thus, few who graduated high school during the Cultural Revolution ended up attending college, and it took almost a decade for China's higher education system to recover as the number of college students only gradually increased during the 1980s.

We assess the long-run human capital cost of the Cultural Revolution by examining the education background of CEOs of listed companies in China - focusing on those CEOs who would have entered college during the Cultural Revolution. We examine the relation between a company's innovation expenditures, innovation output, and the education of its CEO. Specifically, we look at firm R\&D expenditures, patents, and a measure of firm innovation efficiency to test whether these innovation inputs and outputs are related to whether the CEO has a college degree. We use data from China Stock Market \& Accounting Research Database and Wind Economic Database ranging from the year of 2008 to 2016 and construct a panel dataset for all listed companies in China. We control for year and firm fixed effects and also examine firms surrounding exogenous CEO turnovers, which occur when the CEO is close to their mandatory retirement age as in Dittmar and Duchin (2006).

We identify CEOs who were unlucky to have been born during 1948-1958, thus turning 18 during the Cultural Revolution and sharply reducing their chance of going to college. We create a binary variable, denoted as Unlucky, to indicate if the CEO was born during this period. We use this variable to instrument whether a CEO has a college degree. This instrumental variable is highly correlated with our core explanatory variable, CEO College Degree, and should have little impact on firm's innovation policies except through the channel of CEO education. We use the Unlucky instrument both in the full sample and in the exogenous turnover sample.

In all of our tests, we find that firms led by a CEO without a college degree have lower firm R\&D expenditures, fewer patent applications, fewer granted patents and fewer patent citations. These results hold within firms, thus removing firm-specific permanent 
characteristics. The results also hold when the college degree of the CEO is instrumented by our Unlucky instrument that identifies when a CEO turned 18 during the Cultural Revolution thus impacting whether or not they were able to attend college after high school. This instrument is completely exogenous to CEO characteristics other than age, as the Cultural Revolution impacted all college age individuals during this period. Our results support the idea that decreased access to education and less available human capital have long lasting negative effects for firms, as the Cultural Revolution sharply reduced the stock of experienced CEOs that have a college education.

We extend our analysis and apply a regression discontinuity design methodology using the 1977 policy shock when Deng Xiaoping ended the college prohibition. We take advantage of the fact that CEOs who reached the age of 18 before 1977 had a much lower probability of attending college, as they either had to prepare for the entrance exam while still working full time or had to opt for part-time college studies. Our regression discontinuity results show that firms with CEOs turned 18 prior to 1977 during the Cultural Revolution have lower R\&D expenditures and fewer patent applications, and also fewer patent citations compared to those firms with CEOs turning 18 in 1977 or afterwards. Both the instrumental variable results and the regression discontinuity results show a large economic effect on innovation associated with having a college educated CEO. The results add to evidence that education not only serves as a signal for CEOs’ capabilities, but also increases human capital inside the firm.

The question naturally arises: if there is a large benefit to having a college educated CEO, why don’t firms with a non-college educated CEO replace him? Several factors could explain this question. First, CEO accession in China frequently involves internal promotion of existing management based on seniority and political connections. ${ }^{2}$ Because the Cultural Revolution deprived a full cohort of college access, promoting someone with a college education to CEO is often not possible without promoting someone of a younger age over those with more seniority, which is uncommon in China.

Second, the supply of educated CEOs is rather limited in China, partially due to the Cultural Revolution. The median CEO age of our sample is 55 years old. In 2012, the middle

2 See Cao, Pan and Qian (2011), Fan, Wong and Zhang (2007), You and Du (2012). 
year of our sample, the college graduate proportion of the population aged between 50 to 60 is approximately $0.75 \%$, calculated using data from the China Statistical Yearbook. Currently, 49.21\% of CEOs in China do not have a college degree, which is a large fraction relative to CEOs in the West. In contrast, in the U.S. only 8.3\% of Forbes 800 CEOs in the years 19871996 do not have college degrees, as documented by Jalbert, Rao and Jalbert, (2002) and Jalbert, Jalbert and Perrina (2004).

Third, the importance of the CEO’s education for managing or appointing other innovative employees may not be recognized in China as important to overall corporate innovation. All of these cultural and historical factors may explain why a much smaller fraction of Chinese companies have college-educated CEOS relative to the West, despite evidence of their benefits.

Our paper adds to the literature studying the importance of human capital. Romer (1990) includes human capital in the macroeconomic production function and shows how human capital stock can impact an economy’s growth rate. Mankiw, Romer and Weil (1992) develop an augmented Solow model that includes the accumulation of human capital and show that it provides an excellent description of cross-country differences in growth rates. Barro (2001) emphasizes the role of education as a determinant for long term growth. Stroombergen et al. (2002) conclude that human capital is an important source of innovation, driver of sustainable development, and tool for reducing poverty and inequality. More recently, Gennaioli, La Porta, Lopez-de-Silanes, and Shleifer (2012) point to the paramount importance of human capital in accounting for regional differences in development. Looking at China specifically, Fleisher and Chen (1997) find human capital has played a significant role in the Chinese economic development. Fleisher, Li and Zhao (2009) find human capital also has an important effect on reducing regional inequality in China. Our paper adds to this literature by examining the importance of human capital through education in China on individual firms by emphasizing how human capital influences corporate innovation activity.

Our paper also adds to the literature begun by Bertrand and Schoar (2003) on whether CEO personal traits and experiences influence corporate outcomes. We focus on experiences early in a manager's life. We thus add to the evidence of Malmendier, Tate and Yan (2001), who show that CEOs who grew up during the Great Depression are averse to debt, and Schoar and Zhou (2017) who show that economic conditions at the beginning of a manager's career 
have lasting effects on their career path as a CEO. We also add to the literature on CEOs and innovation. Islam and Zein (2018) find that firms led by "Inventor CEOs" are associated with higher quality innovation. We contribute to this evidence by showing how a CEO's college education influences corporate innovation. ${ }^{3}$

The remainder of the paper is organized as follows. Section 2 describes the interruption of higher education during the Cultural Revolution. Section 3 presents the data and summary statistics. We present our empirical strategy, and discuss the empirical relation between CEO’s college education and firm innovation in Section 4. We address endogeneity concerns in Section and deal with causality issues in Section 5. We conclude in Section 6.

\section{The Cultural Revolution (1966-1976) and the Interruption of Higher Education}

\subsection{Background}

In 1966, Mao Zedong launched the Cultural Revolution, which was a massive sociopolitical movement in China. Mao asserted that some members of the Chinese Communist Party (CCP) had forgotten their original revolutionary ideology, and no longer acted on behalf of the people, and called on the public to act against those alleged bourgeois members. Under such encouragement, millions of young people joined the "Red Guards," a mass student-led movement mobilized and guided by Chairman Mao Zedong. People took action around the nation with the intention of removing all bourgeois practices, and countless individuals died during this movement as a result of violence.

\subsection{Interruption of Higher Education}

Higher education was suspended during the Cultural Revolution, because it was blamed for fostering the spread bourgeois values. The government shut down colleges and universities and cancelled the college entrance examination in 1966. Faculty members and core university staff were sent to special reform "schools" to work on farms and in factories. The Red Guard persecuted white collar professionals: searching their houses, confiscating their property, and

\footnotetext{
${ }^{3}$ Our paper also contributes to the literature about how political distortion of education and destruction of human capital have long-run effects through changes in personal preferences and human capital loss. See Alesina et al. (2007) for evidence on East Germany. See Akbulut-Yuksel M. and Yuksel M. (2015) and Francesco et al. (2019) for the long-term direct and spillover effects of large-scale human capital loss caused by the persecution of Jewish professionals in Nazi Germany.
} 
humiliating and assaulting them in front of crowds of people. Some of them were sent to the May 7 Cadre School (named after Mao Zedong's May 7 Directive of 1966). Mao also asked schools to shorten their educational term, to revolutionize education, and not to allow the bourgeoisie to rule schools. After high school, many students went to factories and farms as workers. An entire generation was deprived of the right to receive higher education.

Several previous authors have documented the scarring effect of the Cultural Revolution. Li and Meng (2017) systematically investigate the effects of the deprivation of college education during the Cultural Revolution. They estimate a marked downward shift in college completion rate for the affected cohorts, i.e., those born in or after 1947, relative to older cohorts. Affected individuals experienced a sizable reduction in their earnings and wealth. Meng and Gregory (2002) show that all socioeconomic groups were adversely affected by the Cultural Revolution, but that children with parents of lower educational achievement and lower occupational status experienced the largest negative impact. Widespread and across-the-board school interruption had a substantial impact on later educational attainment, especially when the interruption occurred at the high school level. The probability that an individual who missed both junior and senior high school would go on to obtain a formal 4-year university degree decreased by about $55 \%$.

\subsection{The Restart of the College Entrance Exam}

The Cultural Revolution came to an end after Mao Zedong died on September 9, 1976. In August of 1977, Deng Xiaoping hosted a meeting on science and education in Beijing. During this meeting, Deng Xiaoping decided to restart the college entrance exam. In December, 1977, the first college entrance examination after the Cultural Revolution was held: 5.7 million candidates took the examination, and 273,000 freshmen were admitted to colleges and universities nationwide. The college entrance examination was held again in the summer of 1978, with 6.1 million applicants and 420,000 enrolled following this exam.

Even after the resumption of college entrance exams, the higher education system still took time to recover. In 1976, the number of faculty and researchers engaged in scientific research in colleges was less than $10 \%$ of the previous high before the Cultural Revolution, and 
laboratories and equipment were seriously damaged. ${ }^{4}$ Though countless people desired to enter universities, the universities lacked the faculty and equipment to take all these students. Consequently, in the 1980s there were few college graduates, and it was only in 1990s that universities began to expand enrollment significantly.

The individuals born between 1948 and 1959 thus suffered from the unexpected shock of the Cultural Revolution. While they were permitted to take the college entrance exam after 1977, in many cases they were supporting a family and they had to compete with recent high school graduates when taking the exam. Thus, the opportunity cost of attending college was likely very high for impacted individuals. While the college entrance exam never set limits on the age of exam takers, an entire unlucky cohort missed their peak opportunity to receive a higher education.

\section{Data and Summary Statistics}

\subsection{Sample Construction}

Our sample consists of companies that are listed on China's two major exchanges: the Shanghai A-share stock market and the Shenzhen A-share stock market. We construct a firmyear panel data set to examine whether a CEO's college education has any influence on firm innovation. The data we use are from the China Stock Market Trading Database and Wind Economic Database. We include years 2008 to 2016. In 2006, the CSRC released the Accounting Rules of China's Enterprises (2006 version) requiring all listed firms to report their annual $R \& D$ expenditures. Companies began to disclose their R\&D expenses in annual reports beginning in 2007. We begin the sample in 2008 to allow the reporting requirements to be fully in place and companies in compliance. We exclude financial industries and also 2-digit CSRC industries in which the average patent count per firm-year is less than one. We thus include firms with no patents if other firms in the same industry have patents, while excluding firms in industries which innovation activity is not crucial.

\footnotetext{
${ }^{4}$ In Tsinghua University, from June 1966 to April 1977, the loss of instruments and equipment was approximately 18 million RMB (nearly half of the total value of original instruments and equipment). More than 10,000 pieces of laboratory furniture were lost, and the number of laboratory staff was reduced from 1100 to 500, among which the number of laboratory technicians was reduced from 480 to 180.
} 


\subsection{Variable Measurement}

\subsubsection{Measuring Educational Background}

In our dataset, each CEO’s degree is measured by a dummy variable, Degree. The variable Degree equals 1 when the CEO's highest degree is secondary school, equals 2 when their highest degree is from a junior college, and equals 3 when their highest degree is an undergraduate degree, equals 4 when their highest degree is a master degree, and equals 5 when their highest degree is a doctoral degree.

In all of our main tests we focus on the impact of having an undergraduate degree or higher. We thus generate a binary variable: College Degree. The variable College Degree equals 1 when Degree is at least 3 , otherwise it equals 0.

\subsubsection{Measuring Corporate Innovation}

We construct our main innovation variables from China Stock Market \& Accounting Research Database and Wind Economic Database. We consider multiple measures of firm innovation: innovation inputs, which we capture through firm R\&D spending scaled by total assets, and also innovation outputs, which we capture through patenting activity. We use two metrics to proxy for the firm's innovation output. Previous literature has shown that the patent application is closer to the actual timing of innovation (Griliches, Pakes, and Hall, 1987). Thus, the first and main metric is the number of patent applications that are filed by each firm in a given year (by the listing firm and all of its subsidiaries). While patent applications better capture the timing of innovation, some patents may not be granted. Therefore, we also examine the number of patents that are eventually granted.

The granted patents count suffers from a truncation problem because there is, on average, a two-year lag between a patent's application date and grant date. Following prior work (Hall, Jaffe and Trajtenberg, 2005; Fang, Lerner and Wu, 2017), to reflect the long-term nature of patent assets, we construct the patent stock measure as follows:

$$
K_{i, t}=(1-\theta) K_{i, t-1}+r_{i, t}
$$

Where:

- $K_{i, t}$ is the patent stock of firm $\mathrm{i}$ in year $\mathrm{t}$ 
- $\theta$ is the rate of depreciation of the patent stock, which is set to $15 \%$ in accordance with prior work

- $r_{i, t}$ is the ultimately granted patents applied for by firm $\mathrm{i}$ in year $\mathrm{t}$.

Additionally, to assess a patent's impact we examine patent citations. We hand-collect patent citation information for every listing firm from the Chinese State Intellectual Property Office (CSIPO). Unfortunately, we are not able to collect citations for patents applied by the listing firm’s subsidiaries.

Citations have two limitations. First, citations also have a natural delay, as they are received after the patent is applied for and granted. Second, citation intensities vary across industries. To adjust for these problems, we follow Hall, Jaffe, and Trajtenberg (2001), and divide the number of citations-per-patent for each firm by the mean of the number of citationsper-patent received by all patents in that year in the same industry as the patent. The adjusted variable is constructed to capture relative citation strength. If it is higher than one, then it implies that a particular patent is cited more than the average patent successfully filed for in the same year, in the same industry.

Due to the right-skewed distributions of patent counts and citations, we take natural logarithm of patent applications, granted patent applications, patent stock, citation counts, citations-per-patent and relative citation strength. To avoid losing firm-year observations with zero patents or citations, we add one to the actual values when calculating the natural logarithm.

Our innovation variables thus capture different stages of firm innovation: R\&D expense reveals the commitment of firm's resources to innovation, patent metrics show the innovation output in generating new knowledge that can in principle be appropriated by the firm, and citations indicate the extent to which those innovations turn out to be "important" and hence presumably more valuable to the firm.

\subsubsection{Control Variables}

We control for additional time-varying firm variables that may also impact firm innovation. Control variables include a measure of capital intensity per employee, firm investment opportunities, firm profitability, and firm size. Capital intensity, CapIntensity, is measured as 
the natural logarithm of the ratio of net property, plant, and equipment divided by the number of employees. We use Tobin's q, the market value of assets divided by the book value of assets, as a measure of investment opportunities. Firm profitability, Cashflow, is measured as cash flow from operations divided by lagged firm size. Firm size is measured as the natural logarithm of total assets. We include an indicator variable to mark if a firm is a state-owned enterprise: SOE equals 1 if the company is a state owned enterprise and 0 otherwise. We also include CEO characteristics, including CEO Age, and Chairman, which is indicator variable that equals 1 when the CEO is also the chairman of the board and zero otherwise.

\subsection{Summary Statistics}

Table 1 presents the summary statistics for our main variables by whether or not the CEO has a college degree (College Degree). We find important differences in the characteristics of firms when comparing the sample means for those run by CEOs with college degrees and those run by CEOs without college degrees. CEOs with college degrees are less likely to work in state-owned firms. The firms at which they work invest more in R\&D (2.64\% of assets vs. $2.06 \%$ of assets) than firms where CEOs without college degrees are hired. Firms led by college CEOs also produce higher innovation outcomes. Firms with college CEOs, on average, generate more patent applications (2.119 vs.1.713), have more patents that are successfully granted (1.870 vs 1.538), and hold a higher stock of patents (2.648 vs. 2.241) than firms without college CEOs. The firms that are run by CEOs with college degrees also receive more citations on average (0.368 vs. 0.326$)$ and their patents have higher relative citation strength (0.406 vs. 0.343 ) than firms run by CEOs without college degrees. The differences between the two groups are statistically significant. 


\section{CEO College Education and Corporate Innovation}

\subsection{Univariate Evidence}

We begin by examining the relation between firm innovation and CEO education for a sample of firms that replace their CEOs. Examining changes at the firm level allows us to control for time invariant firm characteristics. We split the sample into (1) firms that replaced a non-college educated CEO with one with a college degree, (2) firms that replaced a collegeeducated CEO with a CEO without a college degree, and (3) firms with no change in the education of their CEO. We implement a difference-in-difference test to show the results for firms in all of these scenarios (College Degree changes from 0 to 1; College Degree changes from 1 to 0; no change in College Degree).

We examine innovation around CEO turnovers in a $[-3,+3]$ window, where the turnover years are excluded. We first take the mean of each firm's innovation before and after turnover, and therefore calculate firm differences. We winsorize these differences at the $1 \%$ and $99 \%$ levels. For each treatment firm (where CEO turnover does happen), we generate firm differences for all other firms with no turnover in the same industry around the same turnover year, and take the median of these differences as the control sample. Table 2 presents these results, which show that innovation increases when a CEO without a college education is replaced by a CEO with a college education. Panel A shows that the increase in Patent Applications when a non-college CEO was replaced by a college CEO, on average, is about 0.812, and significant at $1 \%$ level, relative to control firms. As for Successful Patent Applications, the mean of the difference between post-turnover period and pre-turnover period is 0.685 and the change is also significant at $1 \%$ level relative to control firms. Whereas for treatment firms that replaced a college-educated CEO with a CEO without a college degree, their Patent Applications experience a decline after CEO turnovers, significant at $1 \%$ level compared to control firms, as shown in Panel C. Panel B reveals that for firms with no change in the education of their CEOs, little change in innovation is found around CEO turnover.

However, the differences we have documented from Table 1 and Table 2 still may be driven by time-varying firm, economy, or industry changes. Therefore, we next examine the relation between college education and innovation in a multivariate regression setup where we include 
year and firm fixed-effects to address the concern that unobserved systematic variation may also be driving the results.

\subsection{CEOs and College Education}

\subsubsection{Stock Market Returns}

We first examine whether investors react more favorably to patents applied for by firms with college educated CEOs. These results indicate whether the stock market participants believe the patents applied for by CEOs with college education have higher value. To ensure that all patents were generated under the leadership of a particular CEO, we require that the same CEO is in place both on the grant date and at least one year before the application date for all the patents approved on a given date $t$ for the firm $i$. We regress cumulated abnormal returns around patent-grant dates against the college degree indicator variable for the CEO, and control for the number of patents granted to the firm on the same day, year fixed effects, industry fixed effects, and other control variables. The control variables include the CEO Tenure, CEO Age, CEO Salary, CEO Ownership Share, an indicator for whether the CEO is also the Chairman of the Board, and indicators for whether the CEO has a background in the government or in the finance industry. All of these variables are defined in Appendix A. We include average CEO tenure and average CEO age over all the patents granted at that date, as there are cases where there are multiple patents granted in a particular year but were applied for under different CEOs. Other controls are defined as in Appendix A.

CAR_CAPM is the stock market cumulative abnormal return, during three-day window [0,

+ 2] around the patent-grant date, and excess return is based on the Capital Asset Pricing Model

(CAPM). Specifically, we fit the market model over [-275,-25] period to get the expected returns on the firm's stock, using the Shanghai Exchange market return and then estimate cumulative abnormal returns over a three-day period $[0,+2]$ around the patent-grant date.

CAR_Market is cumulative market adjusted abnormal return, during the three-day window [0,

+ 2] around the patent-grant date. The excess return is calculated by subtracting the Shanghai 
Exchange market return from the raw stock return.

Table 3 shows the results for the market reactions to the patents. The coefficients on College Degree are all positive and statistically significant, which implies that the patents created by firms with college CEOs are viewed as generating higher value for shareholders.

\subsubsection{Innovation and CEO Education}

In this section, we examine whether firm innovation varies with a CEO’s higher education background using a panel setting and including firm and CEO time varying characteristics. We also include year and firm fixed effects to rule out the possibility that the results are driven by yearly variation or by unobserved characteristics of firms.

We begin our analysis by running panel OLS regressions that relate a CEO’s college experience to a variety of corporate innovation measures. We focus on three main types of innovation measures: R\&D spending decisions, counts of patent number, and counts of patent citations. The independent variable of interest is College Degree, which is a binary variable equal to 1 if the CEO has obtained an undergraduate degree or higher, and equal to 0 otherwise. The coefficient of interest in our regressions is $\beta$, which examines how college education relates to corporate innovation. Specifically, we estimate the following model as our baseline regression:

$$
\mathrm{y}_{\mathrm{it}}=\beta^{*} \text { College } \text { Degree }_{\mathrm{it}}+\alpha^{*} \mathrm{X}_{\mathrm{it}}+\mathrm{V}_{\mathrm{i}}+\mathrm{V}_{\mathrm{t}}\left(+\mathrm{V}_{\mathrm{j}}\right)+\mathrm{V}_{\mathrm{p}}+\varepsilon_{\mathrm{it}}
$$

$y_{\text {it }}$ represents the dependent variables, which include firm's R\&D expenses, number of patent applications, number of granted patents, the number of citations and citations-per-patent, respectively. $i$ indexes the firm, $\mathrm{V}_{i}, \mathrm{~V}_{t}$ are the firm and year fixed effects, $\mathrm{V}_{p}$ are the province fixed effects and $V j$ are the industry fixed effects. We include province and industry fixed effects, which we include in selected regressions instead of firm fixed effects. We also include year*industry fixed effects in regressions with industry fixed effects to control for time trends and variations across industries and provinces.

The baseline results of our paper are presented in Table 4, Panel A and Panel B. For brevity, 
we don't report the coefficients of the control variables in our tables.

We first present firm fixed effects regressions in Panel A. With firm fixed effects, the regressions will only take those observations into consideration where there are changes in the variable College Degree for the identification of the coefficient on College Degree. However, the dependent variables patents and citations have time lags that are different from R\&D/Assets. Thus for these patent related dependent variables, we use the average of the these variables before and after the CEO turnover as the dependent variable and also exclude the CEO turnover year.

The results in Panel A show that R\&D expenditures scaled by total assets is significantly higher when firms switch to a college educated CEO. The estimated coefficient on College Degree is positive with a value of 0.341 , significant at $5 \%$ level. This estimate evaluated at the previous averages in Table 1 implies that having a college CEO increases $R \& D /$ Assets by $16.59 \%$, a substantial effect. The increased R\&D could be because these CEOs value research and innovation more, given they themselves have received a college education and may have more specific technical knowledge or know more about the importance of R\&D.

We also examine innovation outcomes, measured by different metrics of patenting activity and measure patent significance through citations received. As noted before in Section 3, it has been shown that application of patents occur more closely after the real innovation take place, compared to the occurrence of granting of patents, which generally lag two or more years after the application of a patent. Thus, we use the number of patent applications as our main measure of innovation output. We find the estimated coefficient on College Degree is 0.288 , significant at 5\% level. From Table 1, the mean of Patent Applications for firms without college CEOs is 1.713 , also implying the average number of patent applications for those firms is $\exp (1.713)-$ 1 =4.55. So having a college CEO increases Patent Applications by 0.288 , to $0.288+1.713=2.001$. This implies the number of patent applications increases to $\exp (2.001)-1$ $=6.40$, a significant increase compared to the average value of 4.55 for firms without college CEOs implied from Table 1. These findings confirm that patent applications increase after the firm switches to a college educated CEO. We also examine patents granted and find that when CEOs have college degrees, the number of patents applications that are granted is also significantly higher, with the estimated coefficient on College Degree is 0.31. Lastly, companies 
with college CEOs have higher patent stocks, with the estimated coefficient on College Degree is 0.37 .

Taken together, the implication of our baseline result is that companies with college educated CEOs perform significantly better on measures of innovation than companies with non-college educated CEOs. However, while there is evidence these two types of companies differ when it comes to innovation policy and results, there are still concerns that firms with better growth prospects may appoint CEOs with a college education for reasons other than innovation.

\subsubsection{Selection of New CEOs}

In the previous section, we show that companies that have a CEO with a college degree innovate more than firms led by a CEO without a college degree. However, there are still concerns about non-random selection and endogeneity. For example, the board may choose to appoint a new $\mathrm{CEO}$ at the same time it changes its innovation policies. In addition, CEOs may be replaced for poor performance. Under such circumstances, his successor may also implement new innovation and investment policies. In this section, we control for selection by examining firms who replace CEOs either at the time of their retirement or when they die from a sudden death. These replacement decisions are likely to be exogenous and not related to current firm performance or firm policies.

For our sample, strict natural retirement is defined as CEO who leaves his/her position at the legal retirement age which is 60 for men and 55 for women in China. ${ }^{5}$ In this retirement sample, we include the firm-year observations of the naturally departing CEO and his or her successor. Then we examine the change in innovation activity surrounding the retirement years. These turnovers, as they are generally exogenous, have very little possibility of being related to a change of firm characteristics or the retiring CEO's job performance.

Panel A of Table 5 presents summary statistics for the CEO retirement sample. There are 231 instances of CEO retirement with 82 instances where the retiring CEO is replaced by a new CEO with a college degree. Among these 82 replacements, there are 59 cases in which the

\footnotetext{
${ }^{5}$ See Interim Measures of the State Council on the Placement of Elderly, Weak and Disabled Cadres" and "Interim Measures of the State Council on Retirement and Retirement of Workers" (Guofa [1978] 104).
} 
departing CEO had no college degree.

We examine firm R\&D and innovation surrounding the replacement years. Given that innovation changes and outcomes may take some time to be realized, and to avoid abrupt changes of firm policies in the transition years surrounding the CEO replacement, we follow Ditmar and Duchin (2014) and exclude the observations that fall into the range of -1 year, +1 year of the turnover event.

Panel B of Table 5 provides regression results around these natural CEO retirement events. The dependent variables are $R \& D /$ Assets, Patent Applications, Successful Patent Applications, and Patent Stock. Inspection of the results shows that the coefficients on College Degree are positive and significant. The relation between College Degree and Patent Applications is significantly positive at the $10 \%$ level, with an estimated coefficient of 0.264 . The relation between College Degree on Successful Patent Applications is also significantly positive at the $5 \%$ level, with an estimated coefficient of 0.298 . Given more limited observations for R\&D in this sample, the $R \& D$ coefficient is insignificant.

Overall, the results are consistent with CEO education having an impact on innovation in this sample of exogenous CEO replacements.

\section{The Cultural Revolution and its Impact on Education}

In this section, we examine the long-run impact of the Cultural Revolution. We use an instrumental variable approach to deal with endogeneity concerns in this section. In the next section we use a regression discontinuity approach and compare firms with CEOs who reach college age right before the end of the Cultural Revolution to those firms with CEOs who reach college age right after the end of the Cultural Revolution. Both of these approaches examine firm R\&D over 30 years after the end of the Cultural Revolution to measure the long-run impact of the lack of college education.

\subsection{The Unlucky Instrument}

In our instrumental approach, we instrument for whether a CEO has college education using an instrument that we call Unlucky, which equals 1 if the CEO was born during the cohort of 1948-1958, meaning he or she reached 18 during the Cultural Revolution (1966-1977), and 0 otherwise. We present the results of the first stage where we regress the variable College 
Degree on the Unlucky variable. The unlucky generation, as defined above, had a very limited possibility to attend college, not to mention the chance to finish college and get a bachelor's degree., given they spent this period in factories and in the countryside as laborers, not in college. We confirm in Panel A of Table 6 that the variable Unlucky is highly negatively and significantly correlated with our independent variable of interest, College Degree.

We present the results of the IV regression in Table 6, Panel B and report the F-statistic for the statistical relevance of the instrument. We also consider other statistical measures of the relevance of the Cultural Revolution instrument, including the Kleibergen-Paap rk LM statistic, Kleibergen-Paap Wald rk F statistic, Anderson-Rubin Wald statistic and Shea's Partial RSquared. They also are consistent with the validity of the instrument variable approach. The regression results show that instrumented College Degree is significantly positively related to all of our measures of innovation except for successful patent applications. ${ }^{6}$ For example, in column (2), the coefficient on College Degree is 0.679, corresponding to an average increase in Patent Applications of 0.679. In column (7), the coefficient on College Degree is 0.349 (t $=2.4$ ), corresponding to an average increase in Relative Citation Strength of 0.349. Overall, the results are consistent with CEO human capital through education influencing firm innovation expenditures and outcomes.

We do note that the coefficients for IV regression are larger than the uninstrumented OLS coefficients of our baseline regression. There are two explanations for this result. First, for Unlucky, the individuals include both those individuals who would not have attended college even if they were not unlucky, as well as those who were unlucky and would have definitely gone to college if they were not born during 1948-1959. In other words, the subgroups whose decisions are affected by the "Unlucky" shock were constrained by the marginal cost of schooling, rather than by the lack of either desire or ability to benefit from college education, meaning the return to education for these individuals may be higher than other subgroups. Therefore, the local treatment effect at the margin for the excluded individuals could exceed that of the population average treatment effect.

\footnotetext{
6 The Successful Patent Applications variable has truncation problems. Many patent applications filed during the latter years in the sample were still under review and had not been granted.
} 
Second, looking back at section 5.1, we can see the regressions coefficients for the retirement sample, where we have less concerns about selection, are of the same magnitude as that of our whole sample IV regression, which is evidence that when endogeneity concerns are ruled out, the coefficients become larger compared to the baseline regression.

In Table 7, we run the same set of regressions for exogenous turnover sample as in Table 5, Panel B, this time using Unlucky as instrumental variable. The instrumented variable, College Degree, is significantly related to all the innovation variables. The results improve relative to the results in Table 5, Panel B, in terms of magnitude and significance. The coefficients on College Degree take the values of are all positive and significant at the $10 \%$ level or stronger.

To conclude, after removing many endogeneity concerns using both the retirement sample and instrumenting College Degree with the Cultural Revolution experience instrument, our baseline results still hold and we find an positive relation between CEO college education and firm-level innovation.

\subsection{Did the Cutltural Revolution Change Beliefs About Innovation?}

It may still be the case that our instrument, Unlucky, not only represents the rare possibility of this unlucky cohort to attend college, but also caused these who were unlucky to change their beliefs about the value of innovation and perhaps impact their willingness to undertake risky activities such as innovation. The mass political movement of the Cultural Revolution triggered conflict among different groups of people. Economic activity was sharply curtailed and families of intellectuals were persecuted. They may have suffered mentally and physically in the Cultural Revolution and potentially it was their experience during this period, and not the lack of a college education, that impacted their attitude toward R\&D investment.

To deal with this concern, we perform two additional robustness tests. First, we check whether or not Unlucky may have changed beliefs toward innovation even for a sample of individuals that did not attend college. We regress firm innovation, on Unlucky, in the sample where every CEO does not have a college degree. Thus, the variable Unlucky can take on the values of zero and one, but either through choice or through experiencing the Cultural Revolution, all CEOs do not have a college education. In Table 8, Panel A, we show that for 
those firms led by CEOs without college degrees, whether the CEOs have experienced the Cultural Revolution has little to do with firm innovation. All coefficients on Unlucky are statistically insignificant. In Table 8, Panel B, we repeat the regressions at the CEO-individual level and find similar results.

We also examine the effect of our two key independent variables, College Degree and Unlucky, in the same regression to examine if experiencing the Cultural Revolution has an incremental, independent effect when also considering the impact of having a College Degree. Results are shown in Table 9. All coefficients of Unlucky are insignificant, while the coefficients on College Degree are significantly positive and have similar magnitude and significance as the coefficients in Table 4, Panel B. This last test adds to the evidence that variable Unlucky does not have an independent effect on corporate innovation except through the channel of having a college degree.

\subsection{Cultural Revolution Regression Discontinuity}

Our last set of tests examines the relation between CEO education and innovation using a regression discontinuity approach. We apply a regression discontinuity design (RDD), using the year of 1977 (individuals with a birth year of 1959) as the cut-off point. As we have discussed earlier, CEOs who reached the age of 18 before 1977 faced more difficulties in entering college. Thus, if they do not have a college degree, it is less likely a result of their ability and more likely a result of factors outside of their control. We focus on CEOs who reached the age of 18 in years surrounding 1977. We assume that CEOs born in years surrounding 1977 have no other observed or unobserved systematic differences, and the result of having a college degree is simply a random sampling outcome.

We adopt both a reduced form RDD and a fuzzy form RDD. The specific polynomial model is shown below:

$$
\mathrm{y}_{\mathrm{i}}=\beta \operatorname{POST}_{\mathrm{i}}+\alpha \operatorname{POST}_{\mathrm{i}} * \text { EventTime }_{\mathrm{i}}+\alpha * \mathrm{X}_{\mathrm{i}}+\mathrm{V}_{\mathrm{j}}+\mathrm{V}_{\mathrm{p}}+\varepsilon_{\mathrm{i}}
$$

Where $\mathrm{y}_{\mathrm{i}}$ represents the dependent variables. The treatment variable, POST, is a dummy variable, equal to 1 if the year is larger than 1977 and zero otherwise. EventTime is equal to the 
year minus 1977. $X_{i}$ contains control variables, including industry fixed effects and province fixed effects. All variables are averaged and all regressions are run at the CEO individual level.

We conduct the standard checks for RDD validity. Given people do not choose their birth year, the randomness of sample assignments around the cut-off year is guaranteed. Next, we check whether control variables included in the RDD regressions are continuous around the cut-off-point. Appendix B presents the regression for covariates. Panel I shows the results using a ( -3 year, +3 year) window. Panel II shows the results using a $(-5$ year, +5 year) window. The coefficients of POST are insignificant. In this way, we assure there's no significant jump of covariates at the cut-off-point. We also do a seemingly unrelated regression (SUR) test for these regressions to test the null hypothesis that there is no statistical difference among the coefficients for these regressions. When using the $(-3$ year, +3 year) window, the $p$-value for SUR test is 0.1303 , indicating that we can’t reject the null hypothesis.

Table 10 examines the effect of the resumption of the college entrance exam on education outcomes. As shown in Table 10, College Degree is regressed against POST in a probit model. The marginal effects are significantly positive and significant in both columns, consistent with a treatment effect of the Cultural Revolution on obtaining a college degree.

We run both reduced form RDD and a fuzzy form RDD. In the reduced form RDD, we regress innovation against POST as in model (3). Results are shown in Table 11. For the fuzzy RDD model, we use treatment dummy POST directly as the actual instrumental variable for College Degree, and run instrumental variable regressions. Table 12 shows the results for the fuzzy RDD. For each table, Panel A shows the results using a (-3 year, +3 year) window. Panel B shows the results using a (-5 year, +5 year) window. In Panel A, Table 11, the reduced-form RDD estimate in column (2) indicates that the resumption of the college entrance exam had a positive effect of 0.233 on Patent Applications in a $(-3$ year, +3 year) window. The economic magnitude corresponds to a $0.233 / 1.713=13.6 \%$ increase in patent applications for CEOs with college degrees relative to the mean of Patent Applications for firms led by CEOs without college degrees. In Panel A, Table 12, the fuzzy RDD estimate in column (2) is also precisely estimated and confirms this effect. We find a similar and even stronger effect of the resumption on Patent Applications in Panel B, Table 11 and Panel B, Table 12. In a (-5 year, +5 year) window, the coefficients on POST are of greater magnitude and significance. Patenting 
activities show significant increases after the cut-off-year both in Table 11 and Table 12, and $\mathrm{R} \& \mathrm{D}$ also shows some increases in the reduced form RDD in a ( -3 year, +3 year) window.

Overall, the regression discontinuity results are consistent with the conclusion that college education does change CEOs' human capital stock and therefore influences companies' innovation. Our results show that firms that are led by CEOs who had a sharply decreased chance of receiving formal college education due to the Cultural Revolution, $\backslash$ invest less in $\mathrm{R} \& \mathrm{D}$ and patent less.

\section{Conclusions}

We use the period of the Cultural Revolution to examine the importance of human capital through CEO education on corporate innovation over 30 years later. Our tests show that firms led by CEOs without college degrees have lower R\&D expenditures, fewer patent applications, and fewer patent citations. To mitigate selection issues, we identify if CEOs were unlucky to have been born during 1948-1958, giving them a sharply reduced chance of going to college as they would have turned 18 during the Cultural Revolution. We use an instrument, "Unlucky" that identifies whether or not the CEO turned 18 during the Cultural Revolution to instrument our college education variable. This instrument is completely exogenous to CEO characteristics other than age, as the Cultural Revolution impacted all college age individuals during this period. We show that reaching college age during the Cultural Revolution sharply decreases the probability that a CEO has a college degree, while it should have little impact on firm's innovation except through the channel of CEO education. Firms with CEOs with college education, instrumented with this “unlucky" instrument, have higher $\mathrm{R} \& \mathrm{D}$, more patent applications, and higher indicators of innovation success.

We also apply a regression discontinuity design and use the year of 1977, when the college entrance exam was resumed, as the cut-off-year. Firms led by CEOs born right before 1977 who had a sharply lower chance of receiving a college education due to the Cultural Revolution, invest less in R\&D and generate less patents than CEOs born right after 1977.

Our results, using the Cultural Revolution instrument and an exogenous replacement sample as well as using a regression discontinuity approach, all show that firms with a CEO 
without a college education have lower R\&D, fewer patent applications, and lower indicators of innovation success. Our results are consistent with decreased access to education and thus less human capital having long lasting negative effects for firms. Our results also show that socio-political events that interrupt a generation's access to education, such as the Cultural Revolution, have long lasting negative effects for firms and economies that wish to encourage innovation. 


\section{References}

Akbulut-Yuksel M , Yuksel M., 2015. The Long-Term Direct and External Effects of Jewish Expulsions in Nazi Germany. American Economic Journal: Economic Policy 7(3), 58-85.

Alesina, Alberto, and Nicola Fuchs-Schündeln, 2007. Good-bye Lenin (or not?): the Effect of Communism on People's Preferences. American Economic Review 97(4), 1507-1528.

Barro R. J., 2001. Human capital and growth. American Economic Review 91(2), 12-17.

Bertrand, M., Schoar, A., 2003. Managing with style: the effect of managers on firm policies. Quarterly Journal of Economics 118, 1169-1208.

Cao J., Pan X. and Qian M., 2011. Political Connection and Managerial Entrenchment: Evidence from CEO Turnovers in China. SSRN Electronic Journal.

Chen, Fleisher B., 1997. The coast-noncoast income gap, productivity, and regional economic policy in China. Journal of Comparative Economics 25, 220-236.

Dittmar A., Duchin R., 2016. Looking in the rearview mirror: the effect of managers' professional experience on corporate financial policy. The Review of Financial Studies 29(3), 565-602.

Fan J. P. H., T. J. Wong, and T. Y. Zhang, 2007a. Politically-Connected CEOs, Corporate Governance and Post-IPO Performance of China's Partially Privatized Firms. Journal of Financial Economics 84(2), 330-357.

Fang LH., Lerner J., Wu., 2017. Intellectual Property Rights Protection, Ownership, and Innovation: Evidence from China. Review of Financial Studies 30(7), 2446-2477.

Fleisher, Belton, Li Haizheng and Zhao Minqiang ,2010. Human Capital, Economic Growth, and Regional Inequality in China. Journal of Development Economics 92(2), 215-231.

Francesco D., Marcel P. and Michael W., 2019. Historical Antisemitism, Ethnic Specialization, and Financial Development. The Review of Economic Studies 86(3), 1170-1206.

Gennaioli N., La Porta, Lopez De Silanes and Shleifer, 2014. Growth in regions. Journal of Economic Growth 19(3), 259-309.

Griliches Z., Pakes A., Hall B., 1987. The value of patents as indicators of inventive activity. Policy and Technological Performance. Cambridge University Press, 97-124.

Hall, B., Jaffe, A., Trajtenberg, M., 2001. The NBER patent citations data file: lessons, insights and methodological tools. NBER Working Paper No. 8498.

Hall, B. , Jaffe, A. , Trajtenberg, M. , 2005. Market value and patent citations. RAND Journal 
of Economics 36 (1), 16-38 .

Islam E., Zein J., 2018. Inventor CEOs. Journal of Financial Economics. Forthcoming.

Jalbert T., Jalbert M., Perrina G., 2004. Does Degree Earned Matter? An Empirical Analysis of CEOs from Large Firms. Journal of College Teaching and Learning 5(1), 65-73.

Jalbert T., Rao R., Jalbert M., 2002. Does School Matter? An Empirical Analysis of CEO Education, Compensation and Firm Performance. International Business and Economics Research Journal 1(1), 83-98.

Li H. and Li Meng, 2017. Scarring Effects of Deprived College Education during China's Cultural Revolution, working paper.

Malmendier U., Tate G., Yan J., 2011. Overconfidence and Early-Life Experiences: The Effect of Managerial Traits on Corporate Financial Policies. Journal of Finance 66(5), 16871733.

Mankiw N.D., Romer D. and Weil D.N., 1992. A Contribution to the Empirics of Economic Growth. Quarterly Journal of Economics 107, 407-437.

Meng, X., Gregory, R.G., 2002. The Impact of Interrupted Education on Subsequent Educational Attainment: a Cost of the Chinese Cultural Revolution. Economic Development and Cultural Change 50 (4), 935-959.

Romer M., 1990. Endogenous technological change. Journal of Political Economy 98, 71-102.

Schoar A., Zro, L., 2017. Shaped by Booms and Busts: How the Economy Impacts CEO Careers and Management Styles. The Review of Financial Studies 30(5), 1425-1456.

Stroombergen, A., D. Rose and Nana, G., 2002. Review of the Statistical Measurement of Human Capital. Statistics New Zealand working paper.

You J., Du G., 2012. Are Political Connections a Blessing or a Curse? Evidence from CEO Turnover in China. Corporate Governance: An International Review 20(2), 179-194. 
Table 1

Summary Statistics

This table provides summary statistics of main variables for both firms led by CEOs with no college degrees and firms led by CEOs with college degrees. Observations are at the firm-year level.

\begin{tabular}{|c|c|c|c|c|c|c|c|}
\hline & \multicolumn{3}{|c|}{ With College Degree } & \multicolumn{3}{|c|}{ Without College Degree } & \multirow{2}{*}{$\begin{array}{l}\text { Difference } \\
\text { t-Test }\end{array}$} \\
\hline & Mean & Std. dev. & Observations & Mean & Std. dev. & Observations & \\
\hline \multicolumn{8}{|l|}{ Dependent variables } \\
\hline R\&D/Assets (multiplied by 100) & 2.639 & 2.897 & 8475 & 2.055 & 2.418 & 5858 & 10.947 \\
\hline Patent Applications & 2.119 & 1.773 & 11133 & 1.713 & 1.715 & 9611 & 16.678 \\
\hline Successful Patent Applications & 1.870 & 1.687 & 11133 & 1.538 & 1.629 & 9611 & 14.343 \\
\hline Patent Stock & 2.648 & 1.986 & 9174 & 2.241 & 1.967 & 7784 & 13.350 \\
\hline Citations & 0.368 & 0.907 & 8753 & 0.326 & 0.831 & 7367 & 3.036 \\
\hline Citations per Patent & 0.076 & 0.232 & 8753 & 0.073 & 0.232 & 7367 & 0.717 \\
\hline $\begin{array}{l}\text { Relative Citation Strength } \\
\text { Independent variable }\end{array}$ & 0.406 & 1.200 & 8403 & 0.343 & 1.077 & 7083 & 3.447 \\
\hline College Degree & 1.000 & 0.000 & 11133 & 0.000 & 0.000 & 9611 & \\
\hline \multicolumn{8}{|l|}{ Control variables } \\
\hline ROA & 0.043 & 0.060 & 11132 & 0.034 & 0.067 & 9610 & 9.393 \\
\hline Cash flow & 0.086 & 5.596 & 10082 & -0.019 & 8.740 & 9067 & 0.998 \\
\hline FirmSize & 21.600 & 1.321 & 10092 & 21.599 & 1.265 & 9078 & -0.078 \\
\hline CEO's Age & 48.314 & 6.269 & 11123 & 49.067 & 6.600 & 9594 & -8.415 \\
\hline Chairman CEO & 0.291 & 0.454 & 11133 & 0.205 & 0.404 & 9611 & 14.268 \\
\hline Tobin's $q$ & 3.001 & 2.744 & 10871 & 2.608 & 2.689 & 9409 & 10.277 \\
\hline CapIntensity & 11.737 & 1.766 & 11037 & 11.731 & 2.025 & 9485 & 0.211 \\
\hline SOE & 0.356 & 0.479 & 11133 & 0.500 & 0.500 & 9611 & -21.123 \\
\hline
\end{tabular}


Table 2

Innovation around CEO turnovers

This table provides Diff-in-Diff t-test results of main dependent variables around CEO turnover in a [-3, +3] window, where the turnover years are excluded. We first take the mean of each firm's innovation before and after turnover, and therefore calculate firm diffs. For each treatment firm (where turnover does happens), we generate firm diffs for all firms in the same industry around using the same turnover year, and take the median of these diffs as control industry diff. R\&D/Assets is multiplied by 100 in all tables. Panel A to Panel C each represent the results for different types of treatment firms’ CEO turnover, with each table reports the mean of firm diffs, the mean of industry diffs, and the t-statistics for diff-in-diff, and the last 2 columns of each table reports the results when treated firms' diffs are winsorized at $1 \%$ and $99 \%$ levels. Panel A is based on the sample where the replacement CEO has a college degree and replaces a CEO without a college degree. Panel B based on the sample where both the replacement and old CEO do not have college degrees. Panel C is based on the sample where the replacement CEO does not have a college degree and replaces a CEO with a college degree. .

\section{Panel A: Turnover where a new college CEO replaces a CEO without a college degree}

\begin{tabular}{|c|c|c|c|c|c|c|}
\hline & \multicolumn{2}{|c|}{ Treated Firms } & \multirow{2}{*}{$\begin{array}{l}\text { Control Firms( Industry } \\
\text { Median) } \\
\text { Mean of industry diff }\end{array}$} & \multirow{2}{*}{$\begin{array}{l}\text { Diff-in- } \\
\text { Diff } \\
\text { T-statistic }\end{array}$} & \multirow{2}{*}{$\begin{array}{l}\text { Winsorized Treated } \\
\text { Firms } \\
\text { Mean of firm diff }\end{array}$} & \multirow{2}{*}{$\begin{array}{l}\text { Diff-in- } \\
\text { Diff } \\
\text { T-statistic }\end{array}$} \\
\hline & $\begin{array}{l}\text { Mean of firm } \\
\text { diff }\end{array}$ & \#Firms & & & & \\
\hline $\begin{array}{l}\text { R\&D/Assets (multiplied by } \\
100 \text { ) }\end{array}$ & 1.052 & 55 & 0.81 & 1.411 & 1.047 & 1.402 \\
\hline Patent Applications & 0.812 & 55 & 0.43 & 3.105 & 0.812 & 3.105 \\
\hline Successful Patent Applications & 0.685 & 55 & 0.269 & 3.572 & 0.685 & 3.572 \\
\hline
\end{tabular}


Panel B: Turnover where the new and replacement CEO both do not have a college degree

\begin{tabular}{|c|c|c|c|c|c|c|}
\hline & \multicolumn{2}{|c|}{ Treated Firms } & \multirow{2}{*}{$\begin{array}{l}\text { Control Firms( Industry Median) } \\
\text { Mean of industry diff }\end{array}$} & \multirow{2}{*}{$\begin{array}{l}\text { Diff-in-Diff } \\
\text { T-statistic }\end{array}$} & \multirow{2}{*}{$\begin{array}{l}\text { Winsorized Treated Firms } \\
\text { Mean of firm diff }\end{array}$} & \multirow{2}{*}{$\begin{array}{l}\text { Diff-in-Diff } \\
\text { T-statistic }\end{array}$} \\
\hline & Mean of firm diff & \#Firms & & & & \\
\hline R\&D/Assets & 0.993 & 127 & 0.758 & 1.384 & 1.027 & 1.715 \\
\hline Patent Applications & 0.374 & 127 & 0.382 & -0.135 & 0.374 & -0.139 \\
\hline Successful Patent Applications & 0.262 & 127 & 0.269 & -0.137 & 0.264 & -0.102 \\
\hline
\end{tabular}

Panel C: Turnover where a CEO with a college degree is replaced by a CEO without a college degree

\begin{tabular}{|c|c|c|c|c|c|c|}
\hline & \multicolumn{2}{|c|}{ Treated Firms } & \multirow{2}{*}{$\begin{array}{l}\text { Control Firms( Industry Median) } \\
\text { Mean of industry diff }\end{array}$} & \multirow{2}{*}{$\begin{array}{l}\text { Diff-in-Diff } \\
\text { T-statistic }\end{array}$} & \multirow{2}{*}{$\begin{array}{l}\text { Winsorized Treated Firms } \\
\text { Mean of firm diff }\end{array}$} & \multirow{2}{*}{$\begin{array}{l}\text { Diff-in-Diff } \\
\text { T-statistic }\end{array}$} \\
\hline & Mean of firm diff & \#Firms & & & & \\
\hline R\&D/Assets & 0.55 & 22 & 0.638 & -0.314 & 0.569 & -0.257 \\
\hline Patent Applications & -0.077 & 22 & 0.381 & -2.034 & -0.035 & -2.026 \\
\hline Successful Patent Applications & -0.067 & 22 & 0.26 & -1.586 & -0.029 & -1.535 \\
\hline
\end{tabular}


Table 3

Stock market returns around patent-grant dates

This table presents the results from OLS regression of cumulative stock market abnormal returns (CARs) around patent-grant dates on our core independent variable, College Degree. CAR_CAPM is cumulative abnormal return, during three-day window $[0,+2]$ around the patent-grant date, and excess return is based on the Capital Asset Pricing Model (CAPM) using the Shanghai Stock Market Return. CAR_Market is the stock market cumulative abnormal return, during the three-day window $[0,+2]$ around the patent-grant date, and excess return is generated by deducting the Shanghai market return from the raw stock return. Number of patents refers to the number of patents granted to the firm on the same day. Average tenure (CEO age) is computed as the mean of the values of tenure (CEO age) corresponding to the patents granted to the firm on the same day. We require that the CEO be the same one when the independent variables and the dependent variable are estimated. Year fixed effects and industry fixed effects are included in each regression. All variables are defined as in the Appendix A. T-statistics are in parentheses.* Indicates significance at $10 \%$ level; ** significance at $5 \%$ level; *** significance at $1 \%$ level.

\begin{tabular}{lllll}
\hline & CAR_CAPM & CAR_Market & CAR_CAPM & CAR_Market \\
\cline { 2 - 4 } & $(1)$ & $(2)$ & $(3)$ & $(4)$ \\
\hline College Degree & $0.00508^{* * *}$ & $0.00468^{* * *}$ & $0.00507^{* * *}$ & $0.00482^{* * *}$ \\
NumPatent & $(9.99)$ & $(8.73)$ & $(10.08)$ & $(9.03)$ \\
& $0.000533^{* * *}$ & $0.000772^{* * *}$ & $0.000529^{* * *}$ & $0.000765^{* * *}$ \\
Tenure & $(5.09)$ & $(7.18)$ & $(5.06)$ & $(7.11)$ \\
& $-0.000348^{* * *}$ & $-0.000242^{* * *}$ & $-0.000344^{* * *}$ & $-0.000244^{* * *}$ \\
Age & $(-6.98)$ & $(-4.69)$ & $(-6.87)$ & $(-4.71)$ \\
& $0.0000755^{*}$ & $0.0000925^{* *}$ & 0.0000698 & $0.0000800^{*}$ \\
Other Controls & $(1.76)$ & $(2.04)$ & $(1.61)$ & $(1.73)$ \\
Year F.E & & & & \\
Industry F.E. & No & No & Yes & Yes \\
Observations & Yes & Yes & Yes & Yes \\
Adjusted-R2 & Yes & Yes & 216932 & Yes \\
\hline
\end{tabular}


Table 4

CEO College Degree and Firm Innovation

This table provides OLS regression results of the main dependent variables on our core independent variable, College Degree. This sample is based on China's listed companies from 2008 to 2016 with non-missing values, consisting of companies operating in the 2-digit industrial classification of the China Securities Regulatory Commission (CSRC) industries where the average patent number per company in the industry is at least one. Financial firms are excluded. Panel A reports the firm fixed effects regression results. Panel B represents the industry fixed effects regression results for seven different dependent variables, R\&D/Assets (multiplied by 100), Patent Applications, Successful Patent Applications, Patent Stock, Citation, Citation per Patent and Relative Citation Strength. All variables are defined as in the Appendix A. Control variables are included in each regression. In Panel B, year fixed effects, industry fixed effects, province fixed effects, year*industry fixed effects are included in each regression. The standard errors are clustered at province*year level. T-statistics are in parentheses.* Indicates significance at $10 \%$ level; ** significance at $5 \%$ level; *** significance at $1 \%$ level.

\section{Panel A: Within firm changes: Firm fixed effects}

\begin{tabular}{|c|c|c|c|c|c|c|c|}
\hline \multirow[t]{2}{*}{ Dependent variable } & $\mathrm{R} \& \mathrm{D} /$ Assets & $\begin{array}{l}\text { Patent } \\
\text { Applications }\end{array}$ & $\begin{array}{l}\text { Successful Patent } \\
\text { Applications }\end{array}$ & PatentStock & Citation & Citation per Patent & Relative Citation Strength \\
\hline & $(1)$ & $(2)$ & (3) & $(4)$ & $(5)$ & (6) & $(7)$ \\
\hline \multirow[t]{2}{*}{ College Degree } & $0.341^{* *}$ & $0.288 * *$ & $0.312 * *$ & $0.370 * * *$ & 0.0475 & 0.0398 & 0.046 \\
\hline & $(2.05)$ & $(2.25)$ & $(2.48)$ & $(2.96)$ & $(0.36)$ & $(0.97)$ & $(0.78)$ \\
\hline Controls & Yes & Yes & Yes & Yes & Yes & Yes & Yes \\
\hline Firm fixed effects & Yes & Yes & Yes & Yes & Yes & Yes & Yes \\
\hline Year fixed effects & Yes & Yes & Yes & Yes & Yes & Yes & Yes \\
\hline Cluster at firm & Yes & Yes & Yes & Yes & Yes & Yes & Yes \\
\hline Observations & 1884 & 1929 & 1929 & 2006 & 1732 & 1454 & 1848 \\
\hline R-squared & 0.147 & 0.274 & 0.144 & 0.453 & 0.214 & 0.316 & 0.176 \\
\hline
\end{tabular}


Table 4

Continued

Panel B: Within industry differences: Industry fixed effects

\begin{tabular}{|c|c|c|c|c|c|c|c|}
\hline Dependent variable & $\mathrm{R} \& \mathrm{D} /$ Assets & $\begin{array}{l}\text { Patent } \\
\text { Applications }\end{array}$ & $\begin{array}{l}\text { Successful } \\
\text { Patent } \\
\text { Applications }\end{array}$ & PatentStock & Citation & $\begin{array}{l}\text { Citation per } \\
\text { Patent }\end{array}$ & $\begin{array}{l}\text { Relative Citation } \\
\text { Strength }\end{array}$ \\
\hline & $(1)$ & $(2)$ & $(3)$ & $(4)$ & (5) & $(6)$ & (7) \\
\hline College Degree & $\begin{array}{l}0.236^{* * *} \\
(3.92)\end{array}$ & $\begin{array}{l}0.0905^{* * *} \\
(4.04)\end{array}$ & $\begin{array}{l}0.0698^{* * *} \\
(3.16)\end{array}$ & $\begin{array}{l}0.0392 * \\
(1.81)\end{array}$ & $\begin{array}{l}0.0315^{* *} \\
(2.04)\end{array}$ & $\begin{array}{l}0.00682^{* *} \\
(2.00)\end{array}$ & $\begin{array}{l}0.0158^{* *} \\
(2.13)\end{array}$ \\
\hline Controls & Yes & Yes & Yes & Yes & Yes & Yes & Yes \\
\hline Year fixed effects & Yes & Yes & Yes & Yes & Yes & Yes & Yes \\
\hline Industry fixed effects & Yes & Yes & Yes & Yes & Yes & Yes & Yes \\
\hline Province fixed effects & Yes & Yes & Yes & Yes & Yes & Yes & Yes \\
\hline $\begin{array}{l}\text { Year*Industry fixed } \\
\text { effects }\end{array}$ & Yes & Yes & Yes & Yes & Yes & Yes & Yes \\
\hline Cluster at Province*Year & Yes & Yes & Yes & Yes & Yes & Yes & Yes \\
\hline Observations & 12392 & 18240 & 18240 & 16764 & 14109 & 14109 & 14336 \\
\hline R-squared & 0.5154 & 0.4937 & 0.4796 & 0.4893 & 0.3879 & 0.2857 & 0.2398 \\
\hline
\end{tabular}




\section{Table 5: CEO Retirements}

This table shows what happens around natural CEO retirement events. Panel B provides regression results around exogenous CEO retirement events. All variables are defined as in the Appendix A. The same of control variables, as in Table 4, are included in every regression in Panel B. In Panel B, to avoid the abrupt change of firm policies due to the change of CEO, we exclude the observations that fall into the range of ( -1 year, +1 year) of the turnover event before we run regressions. Year fixed effects, industry fixed effects, province fixed effects, year*industry fixed effects are included in each regression. The standard errors are clustered at province*year level.* Indicates significance at $10 \%$ level; **significance at $5 \%$ level; *** significance at1\% level.

Panel A: Details of exogenous CEO changes

\begin{tabular}{llll}
\hline & Exogenous changes & College Degree Change & Begin to have college degree \\
\hline \#number & 231 & 82 & 59
\end{tabular}

Panel B: Effect of CEO's college degree on innovation

\begin{tabular}{|c|c|c|c|c|}
\hline \multirow[t]{2}{*}{ Dependent variable } & R\&D/Assets & $\begin{array}{l}\text { Patent } \\
\text { Applications }\end{array}$ & $\begin{array}{l}\text { Successful Patent } \\
\text { Applications }\end{array}$ & Patent Stock \\
\hline & (1) & $(2)$ & (3) & (4) \\
\hline \multirow[t]{2}{*}{ College Degree } & 0.277 & $0.264 *$ & $0.298 * *$ & 0.114 \\
\hline & $(0.78)$ & $(1.82)$ & $(2.08)$ & $(0.64)$ \\
\hline Controls & Yes & Yes & Yes & Yes \\
\hline Year fixed effects & Yes & Yes & Yes & Yes \\
\hline Industry fixed effects & Yes & Yes & Yes & Yes \\
\hline Province fixed effects & Yes & Yes & Yes & Yes \\
\hline Cluster at Province*Year & Yes & Yes & Yes & Yes \\
\hline Observations & 380 & 734 & 734 & 588 \\
\hline R-squared & 0.703 & 0.666 & 0.658 & 0.6887 \\
\hline
\end{tabular}


Table 6: Innovation with the Cultural Revolution Instrument

This table provides empirical regression results of instrumental variable regressions with the cultural revolution instrument: Unlucky. Panel A presents the first stage regression of IV. Panel B shows the results of the second stage of the instrumental variable regressions. Year fixed effects, industry fixed effects, province fixed effects are included in each regression. College degree is run against independent variable Unlucky. R\&D / Assets is multiplied by 100 in all tables. The standard errors are clustered at province*year levels. T-statistics are in parentheses.* Indicates significance at $10 \%$ level; **significance at $5 \%$ level; $* * *$ significance at $1 \%$ level.

\section{Panel A: IV first stage}

\begin{tabular}{lc}
\hline Dependent variable & College Degree \\
\hline Unlucky & $-0.097 * * *$ \\
& $(-7.59)$ \\
Controls & Yes \\
Year fixed effects & Yes \\
Industry fixed effects & Yes \\
Province fixed effects & Yes \\
Cluster at Province*Year & Yes \\
Observations & 12385 \\
\hline
\end{tabular}

\section{Table 6}




\section{Continued}

\section{Panel B: IV second stage}

\begin{tabular}{|c|c|c|c|c|c|c|c|}
\hline \multirow[t]{2}{*}{ Dependent variables } & R\&D/Assets & $\begin{array}{l}\text { Patent } \\
\text { Applications }\end{array}$ & $\begin{array}{l}\text { Successful Patent } \\
\text { Applications }\end{array}$ & $\begin{array}{l}\text { Patent } \\
\text { Stock }\end{array}$ & Citation & $\begin{array}{l}\text { Citation } \\
\text { per Patent }\end{array}$ & $\begin{array}{l}\text { Relative } \\
\text { Citation Strength }\end{array}$ \\
\hline & (1) & $(2)$ & (3) & (4) & (5) & (6) & (7) \\
\hline College Degree & $\begin{array}{l}1.607 * * \\
(2.21)\end{array}$ & $\begin{array}{l}0.679 * \\
(1.94)\end{array}$ & $\begin{array}{l}0.389 \\
(1.19)\end{array}$ & $\begin{array}{l}0.647^{*} \\
(1.81)\end{array}$ & $\begin{array}{l}0.864^{* *} \\
(2.52)\end{array}$ & $\begin{array}{l}0.170^{* *} \\
(1.99)\end{array}$ & $\begin{array}{l}0.349 * * \\
(2.4)\end{array}$ \\
\hline Controls & Yes & Yes & Yes & Yes & Yes & Yes & Yes \\
\hline Year fixed effects & Yes & Yes & Yes & Yes & Yes & Yes & Yes \\
\hline Industry fixed effects & Yes & Yes & Yes & Yes & Yes & Yes & Yes \\
\hline Province fixed effects & Yes & Yes & Yes & Yes & Yes & Yes & Yes \\
\hline Cluster at Province*Year & Yes & Yes & Yes & Yes & Yes & Yes & Yes \\
\hline F-statistic & 56.22 & 59.53 & 59.53 & 58.26 & 35.3 & 35.3 & 38.4 \\
\hline Observations & 12392 & 18242 & 18242 & 16764 & 14111 & 14111 & 14336 \\
\hline R-squared & 0.2393 & 0.4758 & 0.4753 & 0.5335 & 0.091 & 0.074 & 0.059 \\
\hline
\end{tabular}


Table 7

CEO Retirement Sample using the Cultural Revolution Instrument

This table shows an IV regression result around exogenous CEO retirement events with College Degree instrumented by Unlucky. All variables are defined as in the Appendix A. $R \& D$ / Assets is multiplied by 100 in all tables. The same control variables, as in Table 4, are included in every regression. Same as in Table 5 , Panel B, we exclude the observations that fall into the range of $(-1$ year, +1 year) of the turnover event before we run regressions. Year fixed effects, industry fixed effects, province fixed effects, year*industry fixed effects are included in each regression. The standard errors are clustered at province*year level.* Indicates significance at $10 \%$ level; **significance at $5 \%$ level; *** significance at $1 \%$ level.

\begin{tabular}{lllll}
\hline Dependent variable & R\&D/Assets & $\begin{array}{l}\text { Patent } \\
\text { Applications }\end{array}$ & $\begin{array}{l}\text { Successful Patent } \\
\text { Applications }\end{array}$ & Patent Stock \\
\cline { 2 - 5 } & $(1)$ & $(2)$ & $(3)$ & $(4)$ \\
\hline College Degree & $3.138^{* * *}$ & $1.761^{* * *}$ & $1.747^{* * *}$ & $2.521^{* * *}$ \\
& $(2.77)$ & $(4.56)$ & $(4.84)$ & $(4.42)$ \\
Controls & Yes & Yes & Yes & Yes \\
Year fixed effects & Yes & Yes & Yes & Yes \\
Industry fixed effects & Yes & Yes & Yes & Yes \\
Province fixed effects & Yes & Yes & Yes & Yes \\
Cluster at Province*Year & Yes & Yes & Yes & Yes \\
F-statistic & 26.83 & 46.58 & 46.58 & 41.66 \\
Observations & 379 & 733 & 733 & 587 \\
R-squared & 0.387 & 0.628 & 0.614 & 0.631 \\
\hline
\end{tabular}




\section{Table 8}

\section{CEOs with no College Degree}

This table provides empirical regression results to support the validity of the instrumental variables. We run regressions where the dependent variables capture innovation, the independent variable of interest is our instrumental variable in the sample where every CEO has no college degree. All variables are defined as in the Appendix A. R\&D / Assets is multiplied by 100 in all tables. Control variable CEO's age is excluded from these regressions. Year fixed effects, industry fixed effects, province fixed effects, year*industry fixed effects are included in each regression. The standard errors are clustered at province*year level. Tstatistics are in parentheses.* Indicates significance at $10 \%$ level; ${ }^{* *}$ significance at $5 \%$ level; ${ }^{* * *}$ significance at $1 \%$ level.

\section{Panel A: Effect of the Cultural Revolution on innovation, using the sample where CEOs have no college degree, firm-year level}

\begin{tabular}{|c|c|c|c|c|c|c|c|}
\hline \multirow[t]{2}{*}{ Dependent variable } & R\&D/Assets & $\begin{array}{l}\text { Patent } \\
\text { Applications }\end{array}$ & $\begin{array}{l}\text { Successful Patent } \\
\text { Applications }\end{array}$ & $\begin{array}{l}\text { Patent } \\
\text { Stock }\end{array}$ & Citation & $\begin{array}{l}\text { Citation } \\
\text { per Patent }\end{array}$ & $\begin{array}{l}\text { Relative } \\
\text { Citation Strength }\end{array}$ \\
\hline & $(1)$ & $(2)$ & (3) & (4) & (5) & (6) & $(7)$ \\
\hline Unlucky & $\begin{array}{l}-0.114 \\
(-1.49)\end{array}$ & $\begin{array}{l}0.043 \\
(1.18)\end{array}$ & $\begin{array}{l}0.039 \\
(1.10)\end{array}$ & $\begin{array}{l}0.039 \\
(1.09)\end{array}$ & $\begin{array}{l}0.029 \\
(1.05)\end{array}$ & $\begin{array}{l}0.008 \\
(1.00)\end{array}$ & $\begin{array}{l}0.0136 \\
(1.04)\end{array}$ \\
\hline Controls & Yes & Yes & Yes & Yes & Yes & Yes & Yes \\
\hline Year fixed effects & Yes & Yes & Yes & Yes & Yes & Yes & Yes \\
\hline Industry fixed effects & Yes & Yes & Yes & Yes & Yes & Yes & Yes \\
\hline Province fixed effects & Yes & Yes & Yes & Yes & Yes & Yes & Yes \\
\hline Year*Industry fixed effects & Yes & Yes & Yes & Yes & Yes & Yes & Yes \\
\hline Cluster at Province*Year & Yes & Yes & Yes & Yes & Yes & Yes & Yes \\
\hline Observations & 5182 & 8631 & 8631 & 7692 & 6570 & 6570 & 6684 \\
\hline R-squared & 0.5055 & 0.4903 & 0.472 & 0.4769 & 0.3756 & 0.3013 & 0.2765 \\
\hline
\end{tabular}


Table 8

Continued

Panel B: CEO individual level: Effect of the Cultural Revolution on innovation, using the sample where CEOs have no college degree

\begin{tabular}{|c|c|c|c|c|c|c|c|}
\hline \multirow[t]{2}{*}{ Dependent variable } & R\&D/Assets & $\begin{array}{l}\text { Patent } \\
\text { Applications }\end{array}$ & $\begin{array}{l}\text { Successful Patent } \\
\text { Applications }\end{array}$ & $\begin{array}{l}\text { Patent } \\
\text { Stock }\end{array}$ & Citation & $\begin{array}{l}\text { Citation } \\
\text { per Patent }\end{array}$ & $\begin{array}{l}\text { Relative } \\
\text { Citation Strength }\end{array}$ \\
\hline & $(1)$ & $(2)$ & (3) & $(4)$ & $(5)$ & (6) & $(7)$ \\
\hline Unlucky & $\begin{array}{l}-0.0676 \\
(-0.61)\end{array}$ & $\begin{array}{l}-0.0821 \\
(-1.39)\end{array}$ & $\begin{array}{l}-0.0865 \\
(-1.53)\end{array}$ & $\begin{array}{l}-0.111 \\
(-1.56)\end{array}$ & $\begin{array}{l}0.0320 \\
(0.80)\end{array}$ & $\begin{array}{l}0.0162 \\
(1.16)\end{array}$ & $\begin{array}{l}0.0208 \\
(0.95)\end{array}$ \\
\hline Controls & Yes & Yes & Yes & Yes & Yes & Yes & Yes \\
\hline Year fixed effects & Yes & Yes & Yes & Yes & Yes & Yes & Yes \\
\hline Industry fixed effects & Yes & Yes & Yes & Yes & Yes & Yes & Yes \\
\hline Province fixed effects & Yes & Yes & Yes & Yes & Yes & Yes & Yes \\
\hline Year*Industry fixed effects & Yes & Yes & Yes & Yes & Yes & Yes & Yes \\
\hline Cluster at Province*Year & Yes & Yes & Yes & Yes & Yes & Yes & Yes \\
\hline Observations & 1787 & 2623 & 2623 & 2470 & 2286 & 2286 & 2286 \\
\hline R-squared & 0.4540 & 0.5828 & 0.5683 & 0.5672 & 0.4297 & 0.3773 & 0.3851 \\
\hline
\end{tabular}


Table 9

The Cultural Revolution Experience and Firm innovation, OLS results

This table provides OLS regression results of the main dependent variables against our core independent variable, College Degree and instrument variable, Unlucky. Regressions results are presented for seven different dependent variables, R\&D/Assets, Patent Application, Successful Patent Applications, Patent Stock, Citation, Citation per Patent and Relative Citation Strength. R\&D / Assets is multiplied by 100 in all tables. All variables are defined as in the Appendix A. The same control variables, as in Table 4, except variable Age, are included in each regression. Year fixed effects, industry fixed effects, province fixed effects, year*industry fixed effects are included in each regression. The standard errors are clustered at province*year level. T-statistics are in parentheses.* Indicates significance at $10 \%$ level; ** significance at $5 \%$ level; *** significance at $1 \%$ level.

\begin{tabular}{|c|c|c|c|c|c|c|c|}
\hline \multirow[t]{2}{*}{ Dependent variable } & R\&D/Assets & $\begin{array}{l}\text { Patent } \\
\text { Applications }\end{array}$ & $\begin{array}{l}\text { Successful Patent } \\
\text { Applications }\end{array}$ & PatentStock & Citation & Citation per Patent & Relative Citation Strength \\
\hline & $(1)$ & $(2)$ & (3) & (4) & (5) & $(6)$ & (7) \\
\hline \multirow[t]{2}{*}{ College Degree } & $0.229 * * *$ & $0.0937 * * *$ & $0.0738 * * *$ & $0.0400 *$ & $0.0311^{* *}$ & $0.00651^{* *}$ & $0.0146^{* *}$ \\
\hline & $(3.81)$ & $(4.20)$ & $(3.33)$ & $(1.86)$ & $(2.05)$ & $(1.97)$ & $(1.97)$ \\
\hline \multirow[t]{2}{*}{ Unlucky } & -0.0589 & -0.00129 & -0.00864 & 0.0108 & -0.00609 & -0.00441 & -0.00496 \\
\hline & $(-1.19)$ & $(-0.05)$ & $(-0.37)$ & $(0.44)$ & $(-0.31)$ & $(-0.97)$ & $(-0.61)$ \\
\hline Controls & Yes & Yes & Yes & Yes & Yes & Yes & Yes \\
\hline Year fixed effects & Yes & Yes & Yes & Yes & Yes & Yes & Yes \\
\hline Industry fixed effects & Yes & Yes & Yes & Yes & Yes & Yes & Yes \\
\hline Province fixed effects & Yes & Yes & Yes & Yes & Yes & Yes & Yes \\
\hline Year*Industry fixed effects & Yes & Yes & Yes & Yes & Yes & Yes & Yes \\
\hline Cluster at Province*Year & Yes & Yes & Yes & Yes & Yes & Yes & Yes \\
\hline Observations & 12402 & 18262 & 18262 & 16785 & 14349 & 14349 & 14349 \\
\hline R-squared & 0.2885 & 0.4933 & 0.4793 & 0.4891 & 0.3841 & 0.2797 & 0.24 \\
\hline
\end{tabular}




\section{Table 10}

\section{RDD Treatment effect of College Degree}

This table shows result using a regression discontinuity design (RDD) treatment effect for CEOs who reached the age of 18 in years surrounding 1977 . College Degree. College Degree is regressed against treatment dummy POST in a probit model to examine the RDD treatment effect of College Degree. K represents the polynomial order of RDD model. Window represents the bandwidth. Industry fixed effects, province fixed effects are included in each regression. The standard errors are clustered at province level. T-statistics are in parentheses.* Indicates significant at $10 \%$; **significant at 5\%; *** significant at $1 \%$.

\begin{tabular}{llc}
\hline Dependent variable & & College Degree \\
\hline POST & $0.067^{* *}$ & $0.038^{* * *}$ \\
& $(2.34)$ & Yes \\
Industry fixed effects & Yes & Yes \\
Province fixed effects & Yes & Yes \\
Cluster at Province & Yes & 1 \\
K & 1 & $(-5,+5)$ \\
Window & $(-3,+3)$ & 2431 \\
Observations & 1232 & 0.0804 \\
Pseudo R2 & 0.1016 & \\
\hline
\end{tabular}




\section{Table 11}

\section{College Degree and Innovation using a Reduced Form RDD}

This table shows results of innovation for college degree CEOs for CEOs who turned 18 during or right after the Cultural Revolution using a reduced form RDD. Innovation measures are regressed against treatment dummy POST. K represents the polynomial order of RDD model. Window represents the bandwidth. Panel A shows the results using a ( -3 year, +3 year) window. Panel B shows the results using a ( -5 year, +5 year) window. $R \& D /$ Assets is multiplied by 100 in all tables. All variables are defined as in the Appendix A. The same set of control variables, as in Table 4, is included in every regression. Industry fixed effects, province fixed effects are included in each regression. The standard errors are clustered at province level. T-statistics are in parentheses.* Indicates significant at $10 \%$; **significant at $5 \%$;** significant at $1 \%$.

\section{Panel A: (-3 year, +3 year) Window, using reduced form RDD}

\begin{tabular}{|c|c|c|c|}
\hline \multirow[t]{2}{*}{ Dependent variable } & R\&D/Assets & $\begin{array}{l}\text { Patent } \\
\text { Applications }\end{array}$ & $\begin{array}{l}\text { Successful Patent } \\
\text { Applications }\end{array}$ \\
\hline & (1) & $(2)$ & (3) \\
\hline POST & $\begin{array}{l}0.317^{*} \\
(1.80)\end{array}$ & $\begin{array}{l}0.233^{* * *} \\
(3.08)\end{array}$ & $\begin{array}{l}0.163^{* *} \\
(2.37)\end{array}$ \\
\hline Industry fixed effects & Yes & Yes & Yes \\
\hline Province fixed effects & Yes & Yes & Yes \\
\hline Cluster at Province & Yes & Yes & Yes \\
\hline K & 1 & 1 & 1 \\
\hline Window & $(-3,+3)$ & $(-3,+3)$ & $(-3,+3)$ \\
\hline Observations & 837 & 1201 & 1201 \\
\hline Adjusted-R2 & 0.2963 & 0.5866 & 0.5653 \\
\hline
\end{tabular}


Table 11

Continued

Panel B: (-5 year, +5 year) Window, using reduced form RDD

\begin{tabular}{|c|c|c|c|}
\hline \multirow[t]{2}{*}{ Dependent variable } & R\&D/Assets & $\begin{array}{l}\text { Patent } \\
\text { Applications }\end{array}$ & $\begin{array}{l}\text { Successful Patent } \\
\text { Applications }\end{array}$ \\
\hline & $(1)$ & $(2)$ & (3) \\
\hline \multirow{2}{*}{ POST } & 0.258 & $0.302 * * *$ & $0.221 * * *$ \\
\hline & $(1.21)$ & $(5.80)$ & $(4.24)$ \\
\hline Industry fixed effects & Yes & Yes & Yes \\
\hline Province fixed effects & Yes & Yes & Yes \\
\hline Cluster at Province & Yes & Yes & Yes \\
\hline K & 1 & 1 & 1 \\
\hline Window & $(-5,+5)$ & $(-5,+5)$ & $(-5,+5)$ \\
\hline Observations & 1701 & 2322 & 2322 \\
\hline Adjusted-R2 & 0.3048 & 0.5576 & 0.5424 \\
\hline
\end{tabular}


Table 12

College Degree and Innovation using Fuzzy Form RDD

This table shows results of the degree effect on innovation, using a fuzzy form RDD. For the fuzzy RDD model, we use treatment dummy POST as the actual instrumental variable for College Degree, and run instrumental variable regressions for College Degree. K represents the polynomial order of RDD model. Window represents the bandwidth. Panel A shows the results using a ( -3 year, +3 year) window. Panel B shows the results using a ( -5 year, +5 year) window. All variables are defined as in the Appendix A. The same set of control variables, as in Table 4, is included in every regression. Industry fixed effects, province fixed effects are included in each regression. The standard errors are clustered at province level. T-statistics are in parentheses. ${ }^{*}$ Indicates significant at $10 \%$; **significant at 5\%; *** significant at $1 \%$.

Panel A: (-3 year, +3 year) Window, using fuzzy form RDD

\begin{tabular}{|c|c|c|c|}
\hline \multirow[t]{2}{*}{ Dependent variable } & R\&D/Assets & $\begin{array}{l}\text { Patent } \\
\text { Applications }\end{array}$ & $\begin{array}{l}\text { Successful Patent } \\
\text { Applications }\end{array}$ \\
\hline & $(1)$ & $(2)$ & $(3)$ \\
\hline College Degree (Instrumented by Post) & $\begin{array}{l}2.749 \\
(0.56)\end{array}$ & $\begin{array}{l}3.811^{*} \\
(1.78)\end{array}$ & $\begin{array}{l}2.747^{*} \\
(1.68)\end{array}$ \\
\hline Industry fixed effects & Yes & Yes & Yes \\
\hline Province fixed effects & Yes & Yes & Yes \\
\hline Cluster at Province & Yes & Yes & Yes \\
\hline $\mathrm{K}$ & 1 & 1 & 1 \\
\hline Window & $(-3,+3)$ & $(-3,+3)$ & $(-3,+3)$ \\
\hline Observations & 873 & 1201 & 1201 \\
\hline Adjusted-R2 & 0.476 & 0.3834 & 0.5226 \\
\hline
\end{tabular}


Table 12

Continued

Panel B: (-5 year, +5 year) Window, using fuzzy form RDD

\begin{tabular}{llll}
\hline Dependent variable & R\&D/Assets & $\begin{array}{l}\text { Patent } \\
\text { Applications }\end{array}$ & $\begin{array}{l}\text { Successful Patent } \\
\text { Applications }\end{array}$ \\
\cline { 2 - 4 } & $(1)$ & $(2)$ & $(3)$ \\
\hline College Degree (Instrumented by Post) & 1.256 & $2.326^{* * *}$ & $1.66^{* * *}$ \\
& $(0.56)$ & $(4.22)$ & $(3.77)$ \\
Industry fixed effects & Yes & Yes & Yes \\
Province fixed effects & Yes & Yes & Yes \\
Cluster at Province & Yes & Yes & Yes \\
K & 1 & 1 & 1 \\
Window & $(-5,+5)$ & $(-5,+5)$ & $(-5,+5)$ \\
Observations & 1701 & 2322 & 2322 \\
Adjusted-R2 & 0.5743 & 0.6477 & 0.6921 \\
\hline
\end{tabular}




\section{Appendix A}

\begin{tabular}{|c|c|}
\hline Variables & Description \\
\hline \multicolumn{2}{|l|}{ Dependent variables } \\
\hline R\&D/Assets & Research and development expenditures, scaled by total assets. $R \& D$ / Assets is multiplied by 100 . \\
\hline Patent & The natural logarithm of one plus the number of patents applied for during the year by the listed company itself, and its branches. \\
\hline Applications & \\
\hline Successful & The natural logarithm of one plus the number of patents granted during the year by the listed company itself, and its branches. \\
\hline Patent Applications & \\
\hline Patent Stock & The stock of granted patents computed according to equation (1), to reflect the long-term nature of patent assets. \\
\hline Citation & The natural logarithm of one plus the number of citations by the patents of the listed company itself. \\
\hline Citation per Patent & The natural logarithm of one plus citations-per-patent of the listed company itself. \\
\hline $\begin{array}{l}\text { Relative Citation } \\
\text { Strength }\end{array}$ & The natural logarithm of one plus citations-per-patent corrected using HJT (2001)'s fixed effect method. \\
\hline CAR_CAPM & $\begin{array}{l}\text { Cumulative abnormal return, during the three-day window }[0,+2] \text { around the patent-grant date. Excess return is based on CAPM. } \\
\text { Specifically, we fit the market model over }[-275,-25] \text { period to get the expected returns on the firm's stock. }\end{array}$ \\
\hline CAR_Market & $\begin{array}{l}\text { Cumulative abnormal return, during the three-day window }[0,+2] \text { around the patent-grant date. } \\
\text { Excess return is generated by deducting market return from the raw stock return. }\end{array}$ \\
\hline
\end{tabular}




\section{Appendix A \\ Continued}

\begin{tabular}{|c|c|}
\hline Variables & Description \\
\hline \multicolumn{2}{|c|}{ Independent variables } \\
\hline College Degree & An indicator variable equal to 1 if the CEO at least owns a bachelor degree, and zero otherwise. \\
\hline CapIntensity & The natural logarithm of the ratio of net property, plant and equipment to the number of employees. \\
\hline CEO's Age & CEO age in years. \\
\hline Tobin's $q$ & The market value of assets divided by the book value of assets. \\
\hline ROA & Return on assets. \\
\hline Firmsize & The natural logarithm of total assets. \\
\hline Cash flow & Cash flow from operation, scaled by lagged firm size. \\
\hline Chairman CEO & An indicator variable equal to 1 when CEO is also the chairman of the board, and zero otherwise. \\
\hline SOE & An indicator variable equal to 1 if the company is a state owned enterprise, and zero otherwise. \\
\hline Unlucky & An indicator variable equal to 1 if the CEO was born during the cohort of 1948-1959, and zero otherwise. \\
\hline POST & An indicator variable equal to 1 if the year exceeds 1977, and zero otherwise. \\
\hline EventTime & A distance variable equal to year minus 1977. \\
\hline NumPatent & The natural Logarithm of the number of patents granted to firm $i$ on the same grant date $t$. \\
\hline Tenure & The mean of the values of tenure corresponding to the patents granted to the firm on the same day. \\
\hline Age & The mean of the values of CEO's age corresponding to the patents granted to the firm on the same day. \\
\hline Salary & The natural Logarithm of CEO’s annual salary. \\
\hline CEO Share & The number of stock shares held by CEO scaled by total shares. \\
\hline GovernmentBack & $\begin{array}{l}\text { An indicator variable equal to } 1 \text { if the CEO has any government background } \\
\text { (Currently does or used to work in the government), and zero otherwise. }\end{array}$ \\
\hline
\end{tabular}




\section{Appendix B}

\section{Balanced covariates}

This table shows the balanced check for covariates of RDD. Covariates are regressed against treatment variable, POST, to examine whether covariates are continuous around the cut-off-year. K represents the polynomial order of RDD model. Window represents the bandwidth. Panel I shows the results using a (-3 year, +3 year) window. Panel II shows the results using a (-5 year, +5 year) window. Definitions of covariates are provided in Appendix A. Industry fixed effects, province fixed effects are included in each regression. Standard errors are clustered at province level. T-statistics are in parentheses.* Indicates significant at $10 \%$; * significant at $5 \%$; $* *$ significant at $1 \%$.

\section{Panel I: (-3 year, +3 year) Window}

\begin{tabular}{|c|c|c|c|c|c|c|c|}
\hline \multirow[t]{2}{*}{ Dependent variable } & ROA & Cash Flow & Firmsize & Chairman CEO & Tobin's $q$ & CapIntensity & SOE \\
\hline & $(1)$ & $(2)$ & (3) & (4) & $(5)$ & $(6)$ & $(7)$ \\
\hline \multirow[t]{2}{*}{ POST } & 0.001 & -0.092 & $-0.161^{*}$ & 0.004 & 0.116 & -0.036 & -0.018 \\
\hline & $(0.2)$ & $(-1.19)$ & $(-1.93)$ & $(0.19)$ & $(0.61)$ & $(-0.30)$ & $(-0.56)$ \\
\hline Industry fixed effects & Yes & Yes & Yes & Yes & Yes & Yes & Yes \\
\hline Province fixed effects & Yes & Yes & Yes & Yes & Yes & Yes & Yes \\
\hline Cluster at Province & Yes & Yes & Yes & Yes & Yes & Yes & Yes \\
\hline K & 1 & 1 & 1 & 1 & 1 & 1 & 1 \\
\hline Window & $(-3,+3)$ & $(-3,+3)$ & $(-3,+3)$ & $(-3,+3)$ & $(-3,+3)$ & $(-3,+3)$ & $(-3,+3)$ \\
\hline Observations & 1260 & 1260 & 1206 & 1260 & 1260 & 1254 & 1260 \\
\hline Adjusted-R2 & 0.1453 & 0.2269 & 0.3201 & 0.0982 & 0.2348 & 0.2526 & 0.2984 \\
\hline
\end{tabular}




\section{Appendix B}

Continued

Panel II: (-5 year, +5year) Window

\begin{tabular}{|c|c|c|c|c|c|c|c|}
\hline \multirow[t]{2}{*}{ Dependent variable } & ROA & Cash Flow & Firmsize & Chairman CEO & Tobin's $q$ & CapIntensity & SOE \\
\hline & $(1)$ & $(2)$ & (3) & $(4)$ & $(5)$ & (6) & $(7)$ \\
\hline \multirow[t]{2}{*}{ POST } & -0.003 & 0.397 & -0.085 & -0.008 & 0.127 & -0.064 & -0.006 \\
\hline & $(-0.82)$ & $(0.54)$ & $(-1.55)$ & $(-0.45)$ & $(0.97)$ & $(-0.64)$ & $(-0.47)$ \\
\hline Industry fixed effects & Yes & Yes & Yes & Yes & Yes & Yes & Yes \\
\hline Province fixed effects & Yes & Yes & Yes & Yes & Yes & Yes & Yes \\
\hline Cluster at Province & Yes & Yes & Yes & Yes & Yes & Yes & Yes \\
\hline $\mathrm{K}$ & 1 & 1 & 1 & 1 & 1 & 1 & 1 \\
\hline Window & $(-5,+5)$ & $(-5,+5)$ & $(-5,+5)$ & $(-5,+5)$ & $(-5,+5)$ & $(-5,+5)$ & $(-5,+5)$ \\
\hline Observations & 2445 & 2334 & 2336 & 2445 & 2445 & 2432 & 2445 \\
\hline Adjusted-R2 & 0.1321 & 0.0265 & 0.2731 & 0.0926 & 0.2217 & 0.2362 & 0.2449 \\
\hline
\end{tabular}

